\title{
UPAYA PENINGKATAN KOMPETENSI GURU BERDASARKAN SYSTEM THINKING
}

\section{Fadhillah ${ }^{1 *}$, Rugaiyah ${ }^{2}$, Nurhattati Fuad 2, Putry Julia ${ }^{1}$}

1 Universitas Serambi Mekkah, 2Universitas Negeri Jakarta

1J1. Unmuha, Batoh, Lueng Bata, Kota Banda Aceh, Aceh 23245, Indonesia

2J1. Rawamangun Muka, RT.11/RW.14, Pulo Gadung, Jakarta Timur, 13220, Indonesia

* Corresponding Author. Email: fadhillah@serambimekkah.ac.id

\begin{abstract}
Abstrak
Penelitian ini bertujuan untuk menemukan masalah mendasar yang menyebabkan uji kompetensi guru rendah beradasarkan berpikir sistem (system thinking) sehingga masalah mendasar tersebut dapat menjadi daya ungkit dalam penyelesaian masalah rendahnya kompetensi mutu dan kompetensi guru di Aceh. Pendekatan Kualitatif digunakan dalam penelitian ini, subjek penelitian terdiri dari guru Sekolah Dasar di Banda Aceh yang dipilih secara random, kepala sekolah dan dinas pendidikan kota. Data dikumpulkan melalui wawancara, dan studi dokumentasi serta kajian literatur Neraca Pendidikan Daerah (NPD) dari tahun 2015 -2017, di hubungkan dengan beberapa hasil penelitian dan pernyataan tokohtokoh pendidikan serta pemerintah terkait masalah Uji Kompetensi Guru. Analisis dimulai dari data reduction, data display, dan conclusion drawing/verification, hasil penelitian menunjukkan bahwa terdapat tiga pilar dalam berpikir sistem sebagai daya ungkit dalam permasalahan rendahnya mutu dan kompetensi guru yaitu reinforcing berkaitan dengan peningkatan kapabilitas guru, balancing berkaitan dengan perubahan sistem proses rekruitmen guru, dan delaying berkaitan dengan politik dan politisasi pendidikan.

Kata kunci: peningkatan kompetensi guru, system thinking, reinforcing, balancing, delaying
\end{abstract}

\section{IMPROVING TEACHER COMPETENCE BASED ON SYSTEM THINKING}

\begin{abstract}
This study aims to find a fundamental problem that causes low teacher competency test based on system thinking so that the fundamental problem can be a leverage in solving the problem of low-quality competency and teacher competency in Aceh. The Qualitative approach was used in this study, the research subjects consisted of randomly selected elementary school teachers in Banda Aceh, the head of the school and the city education office. Data were collected through interviews, and documentation studies as well as a literature review of the Regional Education Balance (NPD) from 2015-2017, linked to several research results and statements from education and government figures regarding the issue of Teacher Competency Test. The analysis starts from data reduction, data display, and conclusion drawing/verification, the results of the study show that there are three pillars in system thinking as leverage in the problem of low quality and teacher competency, namely reinforcing with regard to increasing teacher capabilities, balancing in relation to changes in the recruitment system teacher, and delaying with regard to politics and the politicization of education.
\end{abstract}

Keywords: increasing teacher competency, system thinking, reinforcing, balancing, delaying

Permalink/DOI: http://dx.doi.org/10.21831/amp.v7i1.22066 


\section{Pendahuluan}

Pelaksanaan Uji Kompetensi Guru (UKG) sebagai bagian dari evaluasi dalam menciptakan guru-guru yang professional. Profesional menurut Undang-Undang No 14 Tahun 2005 mengenai Guru dan Dosen (Presiden Republik Indonesia, 2005) adalah sebuah pekerjaan ataupun kegiatan yang dilakukan seseorang terkait dengan keahlian yang dimilikinya. Sehingga berdasarkan keahlian, kecakapan, dan pemenuhan standar mutu oleh seseorang. Sehingga dengan kompetensi yang dimilikinya sehingga melalui hal itu dapat memenuhi kebutuhan hidupnya serta memerlukan pendidikan profesi. Untuk mencapai profesionalisme guru, ditetapkan kebijakan untuk guru memiliki kualifikasi akademik minimal sarjana (S-1) atau Diploma IV (D-IV) tentunya dengan jurusan yang sejalan Harapannya dengan kualifikasi akademik yang sesuai dapat meningkatkan kompetensi guru tersebut. Dimana guru yang professional harus mempunyai keahlian khusus yang sesuai dengan bidangnya. Dimana tugas guru tidak hanya mengajar tetapi juga mendidik dan melatih.

Mendidik berarti meneruskan dan mengembangkan nilai hidup. Mengajar berarti meneruskan dan mengembangkan ilmu pengetahuan dan teknologi. Sedangkan melatih berarti mengembangkan keterampilan-keterampilan kepada peserta didik. (Novauli, 2015). Oleh karena itu, dalam proses mengajar, mendidik dan melatih seorang guru dituntut untuk mempunyai kompetensi yang professional.

Definisi Kompetensi menurut Hoffmann (1999) adalah the term have been identified, one referring to the outputs, or results of training Definisi kompetensi merujuk kepada dua, yaitu ouput dan input. Ouput berkaitan dengan hasil atau kinerja yang kompeten yang telah dilalui oleh seseorang melalui suatu proses. Sedangkan input berkaitan dengan segala seuatu yang dibutuhkan oleh seseorang untuk untuk mencapai kinerja yang kompoten. Boyatzis (1982) menyatakan bahwa competency broadly as an underlying characteristic that could be a motive, trait, skill, an aspect of their self-image or social role, or body of knowledge which they use. Kompotensi disebut sebagai motif, sifat, keterampilan, aspek dari citra diri atau peran social seseorang, atau dasar pengetahuan/ keahlian. Meliputi dua katagori dari kompetensi yaitu aspek pekerjaan yang harus dilakukan dengan kompetensi tertentu dan apa yang dibutuhkan terkait dengan pemenuhan aspek-aspek ketingkat kompetensi yang dibutuhkan. Pernyataan tersebut di dipertegas oleh Woodruffe (1992) bahwa Woodruffe contends that competency is concerned with people's behaviour and is a dimension of behaviour that is relevant to performance in the job. Kompetensi berkaitan dengan perilaku orang dan merupakan dimensi perilaku yang relevan dengan kinerja dalam pekerjaan. Dari definisi ini Woodruffe membedakan kompetensi (perilaku yang orang perlu tampilkan untuk melakukan pekerjaan secara efektif misalnya sensitivitas) dan kompetensi (bidang operasi dan fungsi kerja misalnya pengembangan staf). Selanjutnya Boyatzis (2008) A competency is defined as a capability or ability. Pada perkembangannya banyak sekali pendapat ahli yang menyatakan tentang kompetensi.

Untuk membedakan seseorang itu lebih unggul, rata-rata atau rendah tingkat kompetensinya. Beberapa ahli mengelompokkan kompetensi tersebut kepada tiga kelompok yaitu (1) kompetensi kognitif, seperti pemikiran sistem dan pengenalan pola; (2) kompetensi kecerdasan emosional, termasuk kesadaran diri dan kompetensi manajemen diri, seperti kesadaran diri emosional dan pengendalian diri emosional; dan (3) kompetensi kecerdasan sosial, termasuk kesadaran sosial dan kompetensi manajemen hubungan, seperti empati dan kerja tim (Boyatzis, 1982; Bray, Campbell, \& GRant, 1974; Howard \& Bray, 1988; Kotter, 1982; Luthans, Campbell, \& Grant, 1974). Berdasarkan pendapat ahli diatas dapat disimpulkan bahwa kompetensi terdiri dari pengetahuan, kecerdasan emosional dan sosial.

Menurut Undang-Undang RI Nomor 14 tahun 2005) pasal pasal 10 ayat 1 tentang guru dan dosen (Presiden Republik Indonesia, 2005)menyatakan bahwa kompetensi 
guru meliputi kompetensi pedagogik, kompetensi kepribadian, kompetensisosial, dan kompetensi profesional yang diperoleh melalui pendidikan profesi". Penetapan empat kompetensi tersebut menjadi dasar dan kewajiban bagi setiap guru untuk memiliki kompetensi tersebut dan menjalankannya sesuai dengan ketetapan yang berlaku. Berdasarkan beberapa pendapat di atas dapat disimpulkan bahwa kompetensi merupakan kemampuan atau kapabilitas yang harus dihasilkan oleh seseorang melalui serangkaian proses dan kemampuan yang dimiliki oleh seseorang untuk mencapai kinerja yang kompoten. Dalam ruang lingkup guru, kompetensi merupakan kemampuan yang harus dimiliki dan dicapai oleh guru yang professional mencakup kompetensi pedagogik, kompetensi kepribadian , kompetensi social dan kompetensi professional.

Standar Kompeteni Guru telah ditetapkan melalui Peraturan Menteri Pendidikan Nasional Nomor 16 Tahun 2007 (Menteri Pendidikan Nasional, 2007), Neraca Pendidikan Daerah (NPD) (Kementerian Pendidikan dan Kebudayaan, 2017) memberikan data tentang hasil Uji Kompetensi Guru (UKG) Indonesia yang masih banyak berada di bawah rata-rata dalam skala nasional (lihat Gambar 1).

Untuk nilai rata-rata nasional mencapai nilai 56,69 dari skala nilai 100 . Hal ini menunjukkan bahwa kompetesni guru Indonesia secara nasional masih memiliki banyak masalah yang harus diselesaikan. Untuk mengungkapkan masalah mendasar yang meneybabkan kompetensi guru masih rendah perlu dilakukan kajian terhadap berbagai aspek lainnya. karena pendidikan merupakan sebuah sistem dimana setiap komponen didalam pendidikan saling terkait satu dengan lainnya.

Kompetensi guru yang rendah jika ditinjau dari sudut pandang sistem disebabkan oleh komponen-komponen lainnya seperti akses guru untuk meningkatkan kompetensi nya melalui pemenuhan kualifikasi akademik terhambat karena keterbatasan dana, waktu dan jarak untuk menempuh pendidikan lebih lanjut. Meskipun demikian, ada beberapa kasus yang menarik untuk diteliti lebih lanjut terkait dengan daerah yang mempunyai otonomi untuk memiliki kebebasan mengembangkan potensi pendidikan secara otonom, sumber dana pendidikan yang banyak, tetapi memiliki tingkat kompetensi guru yang rendah.

Hasil Uji Kompetensi Guru Aceh berada pada peringkat ketiga paling bawah dengan skala 48.33 dari skala nasional meskipun kualifikasi akademik guru Aceh sudah mencapai angka 88.65 secara rata-rata ditinjau dari tiap jenjang (ihat Gambar 2).

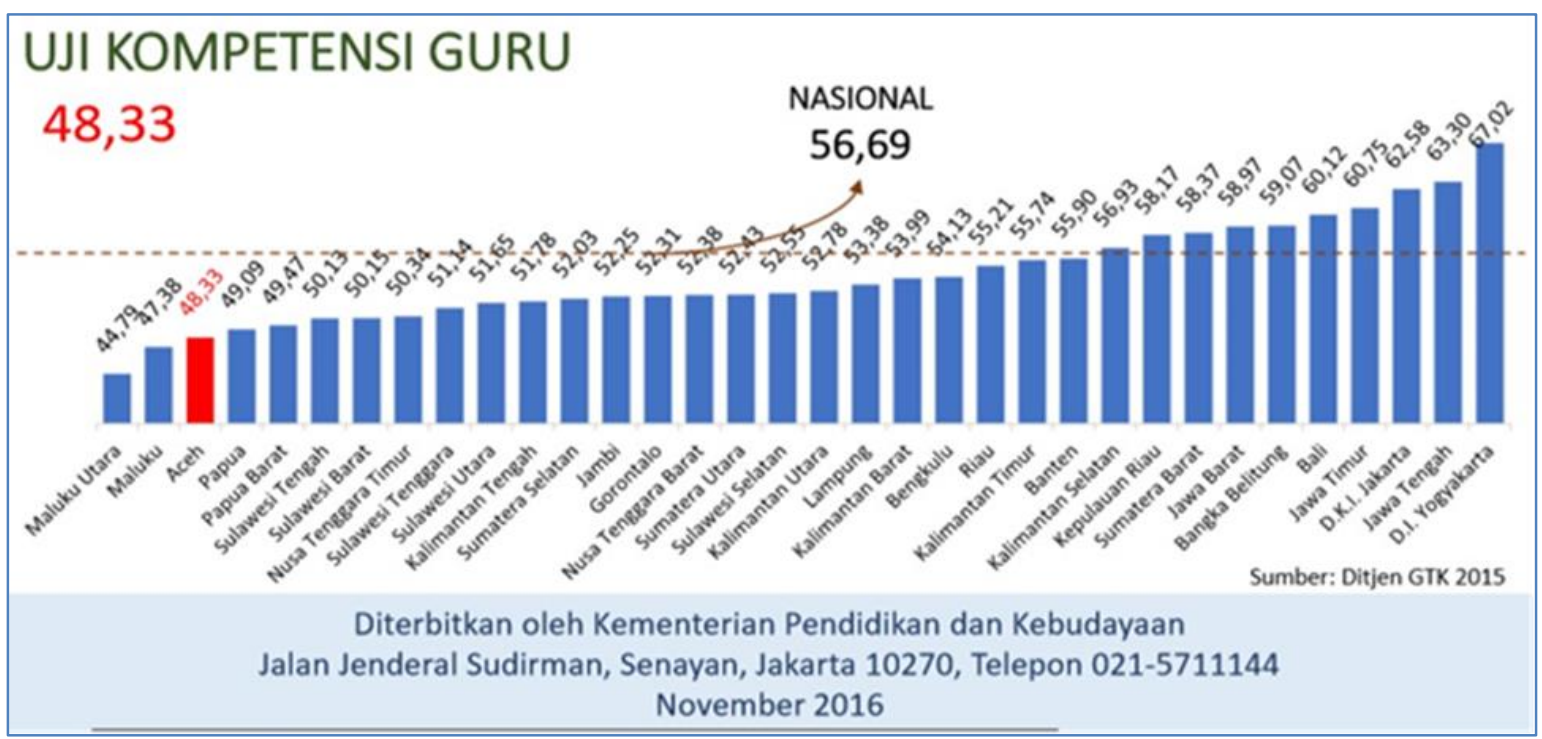

(Kementerian Pendidikan dan Kebudayaan, 2017)

Gambar 1. Uji Kompetensi Guru Skala Nasional 


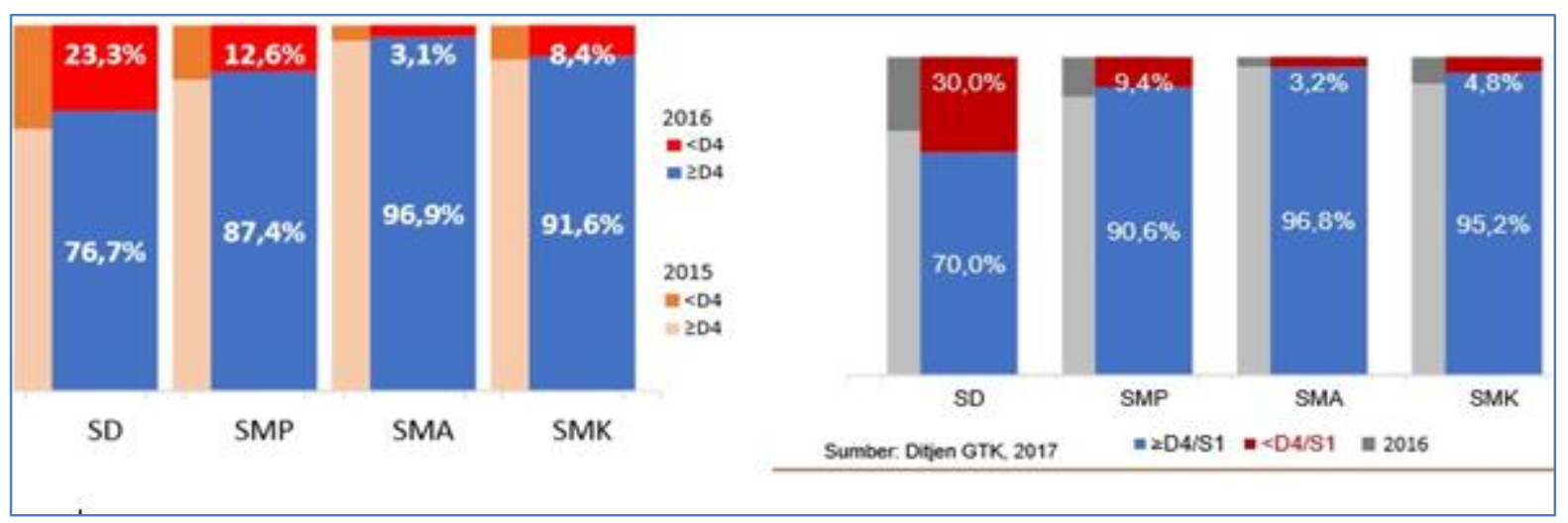

(Kementerian Pendidikan dan Kebudayaan, 2017)

Gambar 2. Perbedaan Kualifikasi Guru tiap Jenjang Pendidikan Tahun 2015 dan Tahun 2016

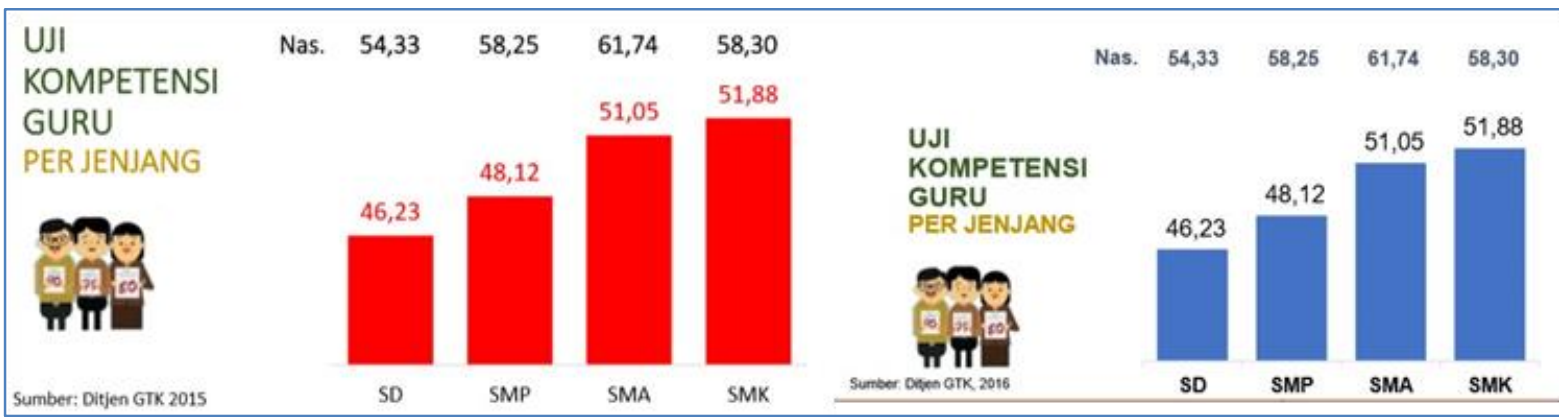

(Kementerian Pendidikan dan Kebudayaan, 2017)

Gambar 3. Hasil Uji Kompetensi Guru Aceh dari Tahun 2015 (Kiri) dan Tahun 2016 (Kanan)

Berdasarkan Gambar 1, terjadi perubahan data yang diterbitkan oleh NPD dari tahun 2016 ke tahun 2017. Ini menunjukkan bahwa terjadi proses yang menggerakkan nilai kualifikasi tersebut, proses itu berkaitan dengan apa saja yang telah diupayakan oleh pemerintah, guru itu sendiri, sekolah, pimpinan dalam mendukung pencapaian peningkatan kualifikasi guru. Untuk tingkat Sekolah Dasar (SD), kualifikasi guru terjadi penurunan 6,7\%, Sekolah Menegah Pertama (SMP) meningkat 3,6 persen, Sekolah Menegah Atas (SMA) menurun 1\%, dan Sekolah Menengah Kejuruan (SMK) meningkat sebanyak 4 persen mengenai kualifikasi guru yang berijazah DIV dan S1.

Hal menarik disini adalah di SD guru yang mempunyai kualifikasi >DIV/S1 menurun, dan terjadi peningkatan pada kualifikasi <D4/S1. Penyebabnya bisa saja guru SD yang mengajar tidak menyelesaikan pendidikan gurunya atau terjadinya pertukaran guru yang mengajar di beberapa sekolah.
Tetapi secara keseluruhan kualifikasi guru di Aceh rata-rata mencapai kualitas yang baik. Tetapi hal tersebut bertolak belakang dengan kompetensi guru Aceh yang rendah (lihat gambar 3). Terlihat dari data tahun 2015 ke tahun 2016, tidak ada peningkatan nilai dari hasil uji kompetensi guru. Semua berjalan flat seperti tidak ada proses apapun. Terlihat sama data nya antara tahun 2015 sampai dengan tahun 2016.

Berdasarkan data di gambar 3. dapat disimpulkan bahwa kualifikasi Guru tidak dapat menjamin kompetensi seorang Guru menjadi profesional. Aceh berada di bawah rata-rata nasional. Aceh menduduki peringkat ke tiga paling bawah dalam uji kompetensi guru dengan nilai 48,33 di bawah rata-rata nasional 56,69.

Oleh karena itu, berdasarkan permasalahan yang tersebut di atas maka melalui hasil penelitian yang di publikasikan melalui tulisan bertujuan untuk mengkaji lebih dalam permasalahan tersebut dengan me- 
nemukan fakta apa saja yang telah dilakukan oleh pemerintah dan guru itu sendiri yang berkaitan dengan peningkatan kompetensi guru berdasarkan teori sistem thinking oleh (Senge, 1990). Sehingga daya ungkit terkait dengan masalah mendasar yang melatarbelakangi rendahnya kompetensi guru tersebut dapat ditemukan dan dijadikan dasar pertimbangan untuk perbaikan dan penetapan kebijakan oleh pemerintah.

\section{Metode Penelitian}

Pendekatan penelitian yang digunakan adalah kualitatif dengan metode survei. Subjek penelitian terdiri dari guru Sekolah Dasar di Banda Aceh yang dipilih secara random dengan sample yang tidak terbatas sampai peneliti menemukan kejenuhan terhadap data yang dikumpulkan, kepala sekolah dan dinas pendidikan kota. Data dikumpulkan melalui wawancara, dan studi dokumentasi serta kajian literature dari Neraca Pendidikan Daerah dari tahun 20152017, di hubungkan dengan beberapa hasil penelitian dan pernyataan tokoh-tokoh pendidikan serta pemerintah terkait masalah Uji Kompetensi Guru. Analisis data model (Miles \& Huberman, 1994) dimulai dari data reduction, data display, dan conclusion drawing/ verification, berdasarkan, selanjutnya ditemukan daya ungkit terhadap masalah tersebut dengan system thinking, dimana terdapat tiga pilar dalam berpikir sistem yaitu reinforcing, balancing, dan delaying (Senge, 1990).

\section{Hasil Penelitian dan Pembahasan}

Kompetensi guru dan permasalahannya.

Permasalahan tentang kompetesni guru telah banyak dikaji dalam bentuk penelitian, pembahasan dan laporan dari pihakpihak terkait. Berikut penulis sajikan permasalah kompetensi guru di Indonesia dari berbagai sudut pandang sebagai berikut.

Berdasarkan hasil penelitian yang dilakukan oleh Nasruddin (2014) menunjukkan: Kepala sekolah melakukan pemberdayaan kompetensi guru, memenuhi persyaratan guru professional, menyediakan sarana dan prasaran pembelajaran yang me- madai; menumbuhkan komitmen terhadap profesionalitas yang melekat pada guru seperti sikap dedikatif, komitmen terhadap mutu proses dan hasil kerja; tetapi pengetahuan akan sistem kinerja oleh guru relatif kurang, kedisiplinan guru dalam pembelajaran siswa relatif lemah, dan perangkat administrasi pembelajaran relatif berat. Selanjutnya, Setiawan (2018) juga mengungkapkan upaya kepala madrasah dalam meningkatkan kompetensi profesional melalui penyusunan program untuk meningkatkan dan mengembangkan kemampuan profesional oleh kepala madrasah, tetapi kemampuan guru dalam Penelitian Tindakan Kelas menjadi kendala dan temuan bberapa kendala lainnya.

Disisi lain Nurhayati (2010) menyimpulkan bahwa kompetensi professional guru dalam merencanakan, melaksanakan, dan melakukan penilaian sudah baik. Namun pemahaman guru tentang pelaksanaan penelitian tindakan kelas (PTK), pemanfaatan TIK serta pengembangan diri masih belum terlaksana, karena kendala yang ada pada guru itu sendiri, organisasi dimana guru itu bekerja dan juga lingkungan. Terdapat hal yang menarik dari pernyataan Nurhayati tersebut bahwa kendala UKG itu terletak pada guru itu sendiri, menurut saya permasalahan ini harus digali secara serius Motivasi internal yang sangat rendah harus didukung dengan kebijakan yang dapat meningkatkan kapabilitas diri guru.

Upaya peningkatan kompetensi guru terus di lakukan oleh pemangku kepentingan pendidikan, seperti kepala sekolah, dinas pendidikan, pemerintah pusat dan daerah serta masyarakat dari berbagai pihak yang peduli terhadap pendidikan. Sebagaimana hasil penelitian oleh Rosita (2015) menunjukkan bahwa upaya peningkatan kompetensi guru yang telah dilakukan meliputi: Program peningkatan kompetensi profesional guru meliputi berbagai pelatihan, mengaktifkan Kelompok Kerja Guru, peningkatan kualifikasi guru dan peningkatan kegiatan ekstrakurikuler. Hambatan-hambatan yang dialami kepala sekolah adalah kurangnya kepedulian guru terhadap kebijakan-kebijakan yang diberikan 
oleh kepala sekolah dan kurangnya tanggung jawab guru terhadap sekolah. Hal ini menujukkan bahwa kapabilitas diri guru secara internal yang menjadi kendala dalam hal pengembangan kompetensi guru.

Selanjutnya Azhari (2014) menyampaikan bahwa hasil penelitiannya menunjukkan bahwa: membina kompetensi profesional guru melalui program-program peningkatan kapasitas guru dalam bentuk supervisi, MGMP, pelatihan dan workshop di madrasah, mengirim guru dalam kegiatan ilmiah dan bekerja sama dengan pengawas. Adapun kendala yang dihadapi kepala madrasah dalam membina kompetensi profesional guru antara lain kurangnya anggaran kegiatan, kurangnya fasilitas, dan lemahnya tingkat keseriusan guru.

Kompetensi guru yang baik, sudah pasti didukung oleh komponen pendidikan lainnya seperti supervisi akademik dan klinis yang diberikan oleh kepala sekolah kepada gurunya. Sebagaimana hasil penelitian (Efendi, 2017). Namun kompetensi supervisi akademik kepala sekolah rendah.

Berdasarkan permasalahan yang telah ditemukan oleh beberapa peneliti di atas, ditemukan keterkaitan kendala yang menjadi dasar permasalah terjadi yaitu masalah kapabilitas, motivasi guru secara internal untuk mengembangkan kompetensi nya masih sangat rendah. Meskipun demikian, ditemukan factor ekternal berdasarkan hasil penelitian dari Rahmatillah, Ruslan, \& Hasan (2017) bahwa kendala dalam pelaksanaan UKG seperti kurangnya persiapan, bentuk soal yang rumit, keterbatasan waktu, lokasi ujian yang jauh, kurangnya sosialisasi yang dilakukan oleh dinas terkait, faktor usia lanjut dan kurangnya penguasaan terhadap informasi teknologi (IT). Simpulan penelitian ini adalah persepsi guru sekolah dasar terhadap pelaksanaan UKG di Aceh Utara sudah baik karena bagi guru UKG ini sangat bermanfaat bagi mereka dalam meningkatkan kualitasnya sebagai seorang guru. Walaupun ada beberapa guru yang kurang setuju dengan UKG ini karena mereka menilai hasil UKG ini bukan menjadi patokan yang sesungguhnya tentang kompetensi dan kualitas mereka.
Berdasarkan temuan diatas, ditemukan masalah lainnya selain dari motivasi internal yaitu kondisi ekternal guru.

Selain dari hasil penelitian yang telah tersebut di atas, penulis juga menemukan kajian dari beberapa sumber lainnya, seperti pernyatan dari Kepala Sekolah SMPN 98 Jakarta yang dikutip oleh Susanti (2015) yakni kepala SMPN 98 Jakarta mengaku siap mengikuti UKG meski masih disibukkan dengan berbagai diklat. Sementara itu, Guru Bahasa Indonesia di SMAN 38 Jakarta mengaku, persiapan yang dilakukannya masih sedikit karena juga harus memikirkan kegiatan di luar sekolah seperti keluarga. Beda halnya dengan Guru Matematika di SMPN 8 Depok, yang mengaku sudah bersiap ujian dengan mencari materi-materi soal UKG di internet. Berdasarkan informasi di atas, dapat diketahui tingkat kesiapan guru dalam menghadapi UKG masih tergolong biasa saja, bahkan ada yang harus memikirkan hal lain seperti kebutuhan keluarga, oleh karena itu komitmen guru dan motivasi guru masih sangat rendah dalam hal peningkatan kompetensi professional guru.

Gubernur Aceh juga membuat kebijakan melalui program Aceh Carong bahwa bagi guru honorer yang akan di kontrak oleh Pemerintah Aceh harus melewati Tes UKG, bagi guru honorer yang memiliki nilai UKG sesuai standarisasi di tetapkan oleh Kemendikbud RI, mereka akan diberikan gaji sesuai UMP Aceh (Anonim, 2018).

Pemerintah Aceh melihat bahwa peningkatan kemampuan pedagogik para guru dan pegiat pendidikan merupakan salah satu hal yang mesti menjadi prioritas yang akan dilaksanakan. Oleh sebab itu, Pemerintah Aceh menetapkan pertemuan rutin untuk dapat menampung ide dan memberi masukan bagi penguatan pedagogik bagi dunia pendidikan di Aceh. Pertemuan rutin ini dinamakan "Greet meeting INDOPED", tujuannya adalah untuk menghasilkan rumusan yang bisa menjadi rujukan bersama dalam meningkatkan kemampuan para guru di daerah ini. Dengan demikian, upaya peningkatan kapasitas guru-guru di Aceh akan berjalan lebih efektif dan terarah. 
Lain halnya dengan Menteri Pendidikan dan Kebudayaan, yang menyatakan bahwa Kemendikbud akan membenahi UK$\mathrm{G}$ nilai 80 hanya berlaku untuk guru muda. Sedangkan guru yang sudah mempunyai pengalaman mengajar lebih lama UKG dapat diambil dari konversi pengalaman kerja (http://www.infokemendikbud.com/).

Upaya pemerintah pusat terkait dengan UKG adalah membedakan nilai UKG guru muda 80 dan guru yang sudah berpengalaman mengajar hanya dengan konversi pengalaman kerja sebagai bentuk penghargaan, karena kemampuan ICT guru senior masih minim. Mengubah syarat sertifikasi dan penulisan karya ilmiah bagi guru.

\section{Konsep Berpikir Sistem}

Sebuah organisasi pembelajar menurut Senge (1990) adalah berfikir secara sistem merupakan tonggak konseptual (concep-tual corner stone) yang mendasari semua pilar disiplin pembelajaran. Berfikir sistem sangat berkepentingan terhadap pergeseran pola fikir (shift of mind) dari cara pandang parsial menuju cara pandang yang holistik. Oleh karena itu berfikir sistem merupakan paradigma yang melihat pada superioritas kesatuan yang menyeluruh (a paradigma premised upon the primary of the whole). Berfikir sistem merupakan disiplin yang melihat fenomena secara keseluruhan sehingga lebih menekankan kepada kerangka pikir yang saling berkaitan (interconnectedness). Berfikir sistem juga merupakan cara pandang yang berfokus pada perubahan (pattern of change) sehingga tidak melihat suatu fenomena yang hanya didasarkan pada cara yang statis. Dalam pengertian yang paling sederhana, berpikir sistem mengajarkan pentingnya berfokus pada gambar besar, dan mengurangi kecederungan berpikir pada tahap detail. Bila diterapkan dalam upaya untuk menciptakan kultur organisasi yang lebih responsif terhadap perubahan, pemikiran sistem akan menuntut anggota organisasi untuk lebih berkonsentrasi pada kecenderungan-kecenderungan besar untuk perubahan, bukan pada kejadian-kejadian kecil sehari-hari. Sehingga dengan berpikir sis- tem akan memberi inspirasi bagi anggota organisasi untuk melihat pola hubungan antar berbagai hal dalam satu kesatuan.

Organisasi belajar hanya melalui individu individu yang belajar. Jika individu menutup individu untuk belajar maka organisasi tersebut sedang bunuh diri secara pelan-pelan. Tidak ada organisasi, tidak ada budaya yang berubah karena mayoritas. Organisasi/budaya dapat berubah hanya melalui individu, ketika perubahan itu sudah diterima oleh kelompok maka akan menjadi kebiasaan dan budaya. Organisasi itu belajar jika individu dalam organisasi tersebut belajar.Tetapi individu yang belajar tidak menjamin organisasi pembelajar karena ada persyaratan tertentu supaya organisasi itu menjadi organisasi pembelajar. Harusnya setiap ide yang muncul baik ide kecil maupun ide besar harus ditampung dan di hargai bukan di bunuh/dimatikan, sehingga bisa menjadi sesuatu yang dapat dimanfaatkan dan dinikmati oleh banyak orang. Harus ada dialog (untuk mencari solusi melalui keterbukaan dari semua yang terlibat dalam dialog) sehingga solusi dapat ditemukan melalui dialog dan memberikan pembentukan kebiasaan untuk organisasi pembelajar harus melalui instutional knowledge secara terus menerus. Tidak terhenti jika salah satu anggota organisasi itu tidak ada atau berhalangan maka organisasi tersebut masih bisa terus berjalan. Organisasi pembelajar adalah sekelompok orang secara terus menerus memperluas kemampuannya untuk menciptakan hasil yang benarbenar mereka harapkan, dimana gambaran berpikir baru dan luas dipupuk, aspirasi kolektif disepakati secara bebas, dan terusmenerus belajar bersama.

Senge (1990) mengemukakan di dalam organisasi pembelajar (learning organization) yang efektif membutuhkan skills yang harus dimiliki oleh setiap personal untuk membangun organisasi pembelajar. Skills tersebut yakni: (1) personal mastery (berkompeten), (2) mental models (pola mental), (3) shared vision (visi yang sama), (4) team learning (tim pembelajar), dan (5) systems thinking (berpikir sistem), sehingga organisasi pembelajar dapat diwujudkan secara 
optimal. Organisasi pembelajar yang optimal dapat memberikan dampak positif terhadap prestasi.

Personal Mastery bukan sekedar kompetensi, tetapi lebih kepada sikap untuk selalu memperbaiki diri. Setiap individu mempunyai kebutuhan dan keinginan untuk belajar. Organisasi itu belajar jika individu dalam organisasi belajar. Individu belajar tidak menjamin organisasi belajar. Seharusnya institutional knowledge harus terbentuk secara terus menerus, melalui generative learning, sehingga tidak terhenti jika salah satu orang tidak ada maka organisasi masih harus terus berjalan/berfungsi.

Mental Model, menghadapi mental model ini biasanya mengajak kita untuk bercermin lebih dalam ke dalam sehingga dapat menemukan titik laverage paling inti dan dapat membetuk transformasi. Mental model berupa template-template yang terbentuk. Sehingga creative learning dan generative learning bisa hilang, oleh karena itu melalui organisasi pembelajar ini adalah untuk mengembalikan kembali generative dan creative learning tersebut. Jika mental model sudah terbentuk, sehingga bisa menjadi mental model organisasi melalui shared mental model.

Team Learning, jika terjadi kesenjangan antara mutu yang baik dan mutu yang buruk, maka akan terjadi proses penyeimbangan untuk berada pada posisi yang sama. Kemungkinan yang mutu baik akan menurunkan standarnya dan mutu kurang akan meningkatkan standarnya sehingga akan terjadi keseimbangan dan sepadan. Hal ini dapat dilakukan melalui proses dialog dalam team learning.

Building Shared Vision, jika visi misi yang telah di ciptakan tidak di shared/dihayati bersama anggota organisasi, maka visi tersebut tidak akan jalan. Oleh karena itu fungsi pemimpin sangat penting untuk membentuk shared/penghayatan the goal secara menyeluruh.

System Thinking dapat digunakan sebagai pendekatan untuk memahami suatu permasalahan, dengan melihat "masalah" sebagai bagian dari sistem keseluruhan, bukan sebagai bagian terpisah yang tidak terkait dengan elemen-elemen yang lain di sekelilingnya. Pendekatan menggunakan System Thinking adalah metode dengan melihat sistem secara holistik dan menganalisanya melalui hubungan sebab akibat dari setiap elemen yang terkait. Jika gagal menemukan sumber kesalahan maka kesalahan tersebut akan mendorong kembali menjadi masalah yang lebih besar. Ada tiga mekanisme penting yang mempengaruhi cara kerja sistem, yaitu reinforcing, balancing dan delaying.

Mekanisme yang mempengaruhi cara kerja sistem adalah sebagai berikut (Senge, 1990): (a) reinforcing, sistem penguatan umpan balik dapat menjadikan kita tidak menyadari sesuatu yang kecil bisa menjadi besar dalam hal baik atau menjadi lebih besar dalam hal buruk melalui penguatan umpan balik. Sesuatu yang kecil jika tidak dihiraukan akan menjadi besar suatu saat nanti melalui proses penguatan yang terjadi secara berulang dan rutin, (b) balancing, ketika seseorang berada pada satu sistem penyeimbangan, maka seseorang berada pada satu sistem yang mencari stabilitas. Dalam upaya menyeimbangkan (menstabilkan sistem), terdapat koreksi diri yang mencoba mempertahankan beberapa tujuan atau target. Proses umpan balik penyeimbangan ada disetiap tempat. Hal ini mendasari bahwa semua perilaku beroerantasi pada tujuan, dan (c) delaying. Penundaan dapat membidik sasaran dengan tidak tepat ataupun tepat jika dapat mengenali bentuk penundaan dan bekerja sejalan dengan penundaan tersebut. Satu titik pengungkit/ pengaruh yang paling tinggi untuk meningkatkan sistem kinerja adalah dengan meminimumkan penundaan sistem. Penundaan terjadi jika akibat dari satu variable terhadap lainnya menyita waktu, merupakan dasar ketiga membangun blok bagi bahasa sistem. Sebenarnya semua proses umpan balik mempunyai beberapa beberapa bentuk penundaan. Tetapi seringkali penundaan tidak dikenali dan dimenegrti dengan baik. Hal ini bisa menghasilkan "hal yang melampau batas" dari apa yang dibutuhkan untuk mencapai suatu hasil yang diinginkan. Penundaan yang tidak dikenali 
bisa mengarah pada ketidakstabilan dan penurunan, terutama bila berlangsung lama.

Peningkatan Kompetensi Guru berdasarkan System Thinking

Uji kompetensi dilakukan untuk memperoleh informasi mengenai penguasaan materi ajar (substansi) dan metode pembelajaran setiap guru. Hasil uji kompetensi ini yang menentukan apakah seorang guru masih dalam kategori layak mengajar atau belum layak mengajar. Selanjutnya, guru yang dikategorikan belum layak mengajar harus diberi pelatihan pendalaman materi. Uji Kompetensi Guru (UKG) merupakan tes yang mengukur penguasaan materi ajar dan metode pembelajaran pada mata pelajaran di jenjang pendidikan tertentu dan merupakan persyaratan minimal seorang guru untuk dapat mengajar. Pengembangan tes mengacu pada Standar Kompetensi Guru yang dikeluarkan oleh Kemdikbud. UKG memiliki tujuan untuk memperkuat peran guru dalam melaksanakan pendidikan. Sehingga guru mampu memberikan dan juga meningkatkan mutu pendidikan di Indonesia. UKG juga dapat digunakan untuk memetakan kondisi objektif setiap guru sehingga dapat dijadikan sebagai informasi penting bagi pemerintah ketika akan mengambil sebuah kebijakan yang terkait dengan materi dan juga strategi dalam memberikan pembinaan yang dibutuhkan oleh guru. Uji kompetensi guru memiliki manfaat yang sangat penting bagi lembaga pendidikan, terutama dalam rangka meningkatkan kualitas pendidikan melalui peningkatan kualitas guru yaitu: (1) sebagai alat untuk mengembangkan dan menetapkan standar profesi guru, (2) merupakan alat seleksi penerimaan guru baru, (3) untuk memetakan kemampuan guru, (4) Sebagai bahan acuan dalam pengembangan kurikulum, (5) merupakan sarana untuk pembinaan guru, (6) mendorong peningkatan proses dan hasil belajar.

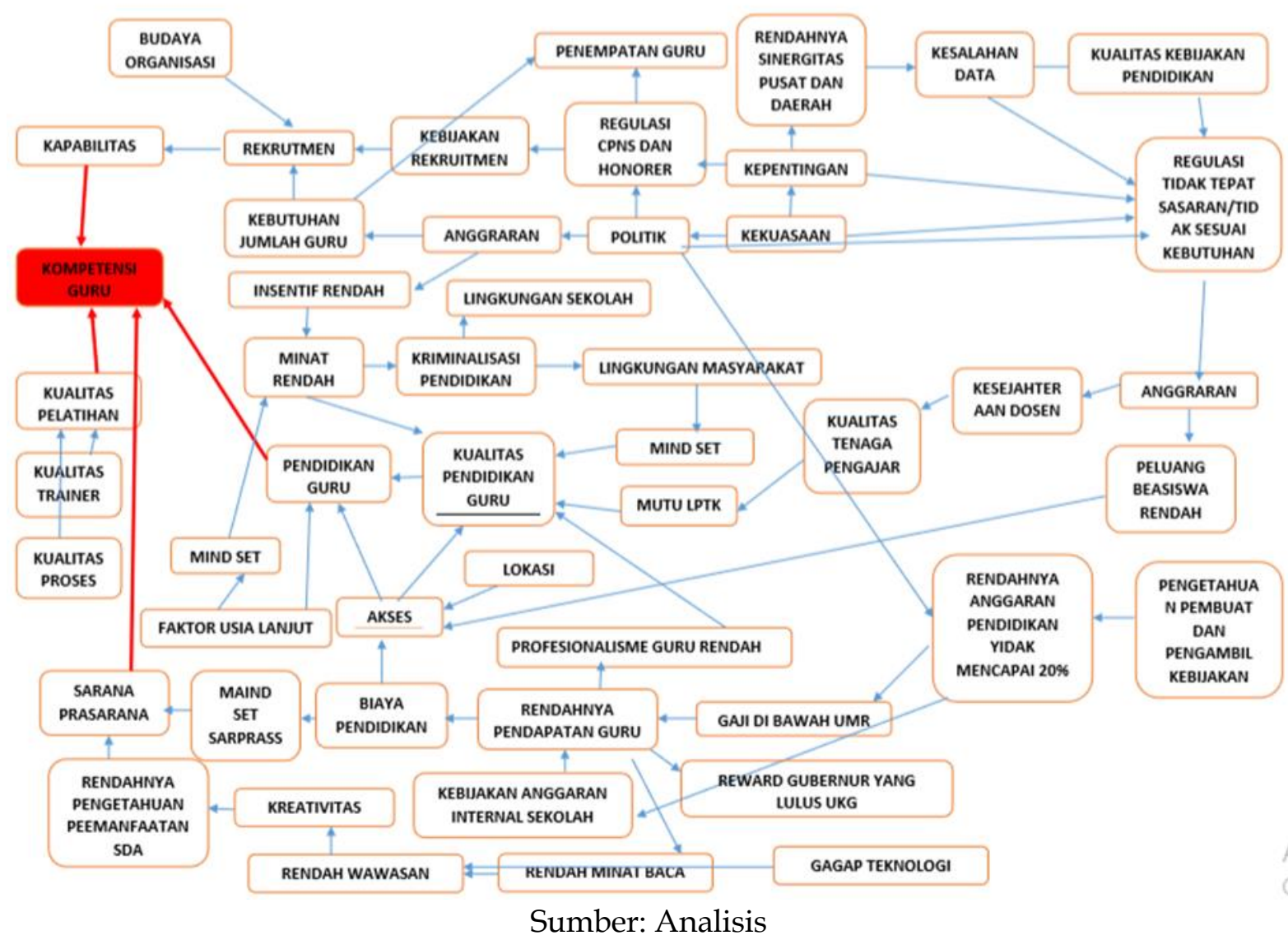

Gambar 4. Analisis Masalah Kompetensi Guru berdasarkan system Thinking 
Apabila dilihat dari sudut pandang berpikir sistem, berdasarkan fakta yang telah di paparkan di atas melalui hasil penelitian terdahulu, telaah dokumentasi dan wawancara mengenai upaya-upaya yang telah dilakukan oleh pemerintah pusat, pemerintah Provinsi dan Kabupaten Kota, Sekolah bahkan guru sendiri dalam meningkatkan kompetensi Profesional guru terlihat dalam permasalahan yang terhubung secara sistem (lihat Gambar 4). Hasil penelitian menunjukkan bahwa ahwa upaya-upaya tersebut ada yang masih dalam tahapan pengutan (Reinforcing), dan bahkan ada yang mencapai proses (Balancing) dan Delaying pada hasil peningkatan kompetensi guru. Berikut akan diuraikan, yang mana saja upaya yang masuk dalam Reinforcing, Balancing, dan Delaying. Tetapi sebelumnya saya akan mencoba untuk memetakan masalah dan mengidentifikasi keterkaitan sistem dari masalah-masalah tersebut.

Berdasarkan pemetaan masalah secara sistemik di Gambar 4, maka dapat ditarik kesimpulan bahwa pada dasarnya segala sesuatu terjadi secara sistem dan saling berhubungan satu dengan lainnya. Meskipun demikian menurut Peter Senge, masalahmasalah tersebut jika dilihat dari sudut pandang berpikir sistem maka akan ditemukan tiga pilar yaitu Reinforcing, Balancing, dan Delaying (lihat Gambar 5).

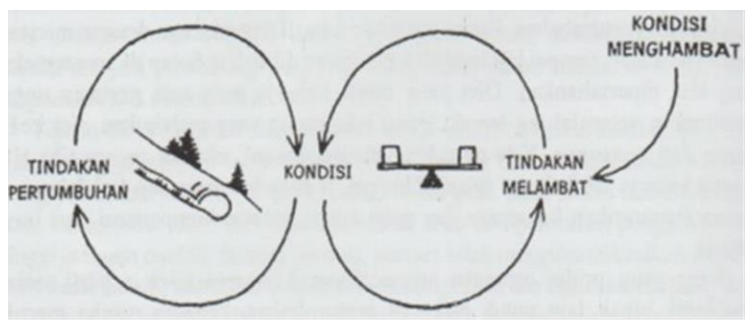

(Senge, 1990)

Gambar 5. Mekanisme yang Mempengaruhi Cara Kerja Sistem

Berdasarkan analisa peta masalah di Gambar 4 di atas, begitu banyak hal yang dilakukan baik oleh pemerintah pusat, provinsi kabupaten kota, kepala sekolah bahkan guru itu sendiri dalam upaya peningkatan kompetensi guru di Aceh.

Meskipun demikian, peneliti mencoba untuk melihatnya dari sudut pandang struktur sistem. Apa yang telah dilakukan di atas, pada umumnya berfokus pada level penguatan/reinforcing saja, seperti mengadakan pelatihan, meningkatkan kualifikasi, melaksanakan supervisi, greet meeting, dukungan dan apresiasi bagi guru yang berprestasi. Tetapi apa yang telah dilakukan tersebut tidak memberikan pengaruh yang signifikan dalam meningkatkan kompetensi guru, buktinya dari tahun 2015 sampai dengan tahun 2016 berdasarkan data Nercana Pendidikan daerah tidak terjadi peningkatan sama sekali terhadap capaian nilai uji kompetensi Guru Aceh, nilainya berada pada posisi yang sama.

Oleh karena itu di butuhkan balancing untuk menyeimbangkan penguatan yang telah dilakukan sebagai evaluasi diri terhadap apa yang telah dilakukan dalam peningkatan kompetensi guru. Selain itu juga hal yang sangat penting mempunyai pengetahuan tentang apa saja yang menyebabkan delaying terhadap proses yang relah dilakukan selama ini. Delaying tersebut perlu untuk dihilangkan atau di antisipasi untuk meningkatkan kecepatan pencapaian terhadap tujuan.

Peningkatan Kapabilitas Guru sebagai Reinforcement

Pemaknaan kapabilitas tidak sebatas memiliki keterampilan (skill) namun lebih dari itu, yaitu lebih paham secara mendetail sehingga benar benar menguasai kemampuannya dari titik kelemahan hingga cara mengatasinya. Hal ini yang harus menjadi fokus penguatan yang dilakukan oleh pemerintah, masyarakat, perguruan tinggi dan sekolah. Rendahnya kapabilitas guru di Aceh di pengaruhi oleh budaya organisasi yang telah terbentuk, dimana guru melaksanakan tugasnya berdasarkan apa yang telah dilihat dan di contoh dari guru senior sebelumnya Sehingga kesalahan yang sama terulang. Hal tersebut sejalan dengan hasil penelitian Syakir \& Pardjono (2015) yang menemukan bahwa secara parsial hanya budaya organisasi yang menunjukkan pengaruh positif dan signifikan terhadap kompetensi guru. Sehingga perlu diciptakan budaya organisasi degan prinsip orga- 
nisasi pembelajar sehingga kesadaran untuk memperbaiki diri yang masih sangat rendah dapat ditingkatkan menjadi lebih positif, bisa juga disebabkan oleh rendahnya pengetahuan guru tentang kompetensi yang harus dimiliki oleh guru professional. Oleh karena itu, perlu adanya kesadaran dari guru itu sendiri dalam upaya peningkatan kompetensi mereka. Sebagaimana hasil penelitian dari Ristiyani \& Wijayanti (2014) upaya para guru dalam meningkatan kompetensi yaitu dengan cara memahami tuntutan standar profesi, etos kerja dan budaya kerja. Berdasarkan permasalan yang tersebut diatas, maka sangat penting untuk melakukan perbaikan secara sistem terhadap peningkatan kapabilitas guru terutama dengan menciptakan budaya organisasi pembelajar, dan merencanakan program peningkatan kapabilitas guru baik melalui pelatihan, motivasi, bahkan regulasi rekruitmen calon guru.

Perubahan secara Sistem terhadap Proses Rekruitmen Guru Sebagai Balancing

Rekruitmen guru yang berlangsung selama ini, melalui proses seleksi calon Pegawai Negeri Sipil (CPNS) dimana kebijakan sekarang memprioritaskan pengangkatan tenaga pendidik bagi yang sudah mempunyai sertifikat Pendidikan Profesi Guru untuk menjamin tenaga pendidik yang profesional, selain itu rekruitmen lainnya melalui tenaga honorer untuk mengisi kekosongan tenaga pendidik akibat dari memorandum pengangkatan tenaga pendidik melalui jalur CPNS. Di Provinsi Aceh ditetapkan kebijakan terkait dengan tenaga pendidik honorer yang diwajibkan mengikuti Uji Kompetensi guru sebagai syarat mendapatkan Gaji sejumlah Upah Minimn Regional (UMR).

Proses rekruitmen tenaga pendidik di Aceh sebelumnya, dipengaruhi oleh faktor daerah yang pernah mengalami bencana konflik dan tsunami, dimana melalui musibah tersebut banyak terjadi kekosongan terhadap jumlah kebutuhan tenaga pendidik, bisa disebabkan oleh faktor kematian, pindah tempat kerja dan sebagainya. Sehingga pada saat itu rekruitmen dilakukan dengan cara pemutihan tenaga honorer diangkat sebagai CPNS secara masal, meskipun seleksi CPNS juga dilaksanakan pada saat itu. Selain itu, proses rekruitmen calon guru di sekolah terkadang masih terikat dengan budaya nepotisme.

Berdasarkan temuan masalah terkait dengan rekruitmen yang telah dilakukan pada masa lalu secara tidak tepat menyebabkan berbagai masalah di kemudian hari seperti ditemukan guru yang tidak dapat mengajar, tidak mempunyai kompetensi guru, tidak berbakat sebagai guru hanya karena tidak ada pekerjaan lain sehingga mencoba untuk menjadi guru sebagai batu loncatan. Sehingga perbaikan yang harus dilakukan terhadap peningkatan kompetensi guru sangatlah komplek karena guru yang telah menjadi guru tidak dipersiapkan secara baik.

Seharusnya proses rekruitmen guru di mulai dari perbaikan mutu LPTK, LPTK di evaluasi kinerjanya dan diberikan pendampingan sehingga menjadi lembaga yang professional, independen, terpercaya untuk melakukan bimbingan dan pengajaran terhadap calon guru. Setelah LPTK dibenahi maka proses rekruitmen guru dapat di mulai dari tingkat LPTK sebagai proses rekruitmen pertama. Setiap calon mahasiwa yang ingin kuliah di LPTK di lakukan serangkaian test dengan instrument yang telah dipersiapkan. Dimana test tersebut hanya meluluskan calon guru yang mempunyai talent guru, benar-benar siap menjadi guru dan bersedia di bimbing, dibina untuk menjadi guru. Jumlah calon guru yang diterima sesuai dengan jumlah kebutuhan guru di sekolah-sekolah setelah dilaksanakn proyeksi jumlah kebutuhan guru beberapa tahun kedepan.

Selanjutnya LPTK membuat kontrak kerjasama dengan beberapa sekolah untuk proses pemebalajaran magang mahasiswa yang telah diterima nantinya. Selanjutnya mahasiswa yang telah lulus dari LPTK langsung mendapatkan tempat magang melalui serangkaian placement test sesuai dengan pendataan jumlah kebutuhan guru di tiap sekolah sebelumnya. Ketika mahasiswa menyelesaikan magang dan dinyatakan lulus 
maka lulusan guru tersebut sudah dapat mengabdikan diri sebagai guru di sekolah. Rekomendasi usulan perubahan secara sistem terhadap proses rekruitmen guru sebagai balancing, dapat dilihat pada Gambar 6 .

Politik dan Politisasi Pendidikan sebagai Delaying

Permasalahan yang sangat mendasar dalam pendidikan yaitu ketika pendidikan dijadikan sebagai senjata politik karena faktor kepentingan dan kekuasaan sekelompok elit politik. Sehingga kebijakan pendidikan yang di tetapkan terkadang tidak menyentuh masalah mendasar pendidikan. Hal ter- sebut menjadi salah satu kendala terhambatnya laju mutu pendidikan di Indonesia. Independensi Pendidikan sangat penting dan urgent untuk diperhatikan. Perubahan ini dapat di mulai dari keterlibatan Orang dengan latarbelakang gelar akademik doktor dan magister yang mempunyai pengetahuan dan dapat berpikir secara sistem dalam membuat kebiajkan dan mengambil keputusan pendidikan. Sehingga mereka menjadi cikal bakal perubahan kebijakan pendidikan yang di politisasi selama ini. Meskipun ini berat untuk di rubah karena sudah mengakar tetapi jika dilakukan secara tersistem dan terencana maka perubahan secara besar-besaran dapat dilakukan.

\begin{tabular}{|c|c|c|c|c|c|}
\hline \multirow[t]{2}{*}{$\begin{array}{l}\text { Perbaikan } \\
\text { Mutu LPTK }\end{array}$} & \multicolumn{5}{|c|}{$\begin{array}{l}\text { menjadi lembaga yang professional, independen, terpercaya untuk } \\
\text { melakukan bimbingan dan pengajaran terhadap calon guru. }\end{array}$} \\
\hline & & & & & $\downarrow$ \\
\hline \multirow{2}{*}{\multicolumn{2}{|c|}{$\begin{array}{l}\text { lakukan } \\
\text { serangkaian test } \\
\text { dengan instrument. } \\
\text { Dimana test } \\
\text { tersebut hanya } \\
\text { meluluskan calon } \\
\text { guru yang } \\
\text { mempunyai talent } \\
\text { guru, benar-benar } \\
\text { siap menjadi guru } \\
\text { dan bersedia di } \\
\text { bimbing, dibina } \\
\text { untuk menjadi guru }\end{array}$}} & & $\begin{array}{l}\text { LPTK Melaksanakan } \\
\text { Rekruitmen I calon guru } \\
\text { berdasarkan kebutuhan }\end{array}$ & \multicolumn{2}{|c|}{$\begin{array}{l}\text { LPTK kerjasama (MoU) dengan } \\
\text { sekolah-sekolah berdasarkan } \\
\text { proyeksi kebutuhan guru di } \\
\text { Indonesia pada masa depan }\end{array}$} \\
\hline & & $\rightarrow$ & $\begin{array}{l}\text { Mahasiswa yang telah lulus } \\
\text { dari LPTK langsung } \\
\text { mendapatkan tempat } \\
\text { magang melalui serangkaian } \\
\text { placement test sesuai } \\
\text { dengan pendataan jumlah } \\
\text { kebutuhan guru di tiap } \\
\text { sekolah sebelumnya }\end{array}$ & $\rightarrow$ & $\begin{array}{l}\text { Mahaiswa menyelesaikan } \\
\text { magang dan dinyatakan } \\
\text { lulus maka lulusan guru } \\
\text { tersebut sudah dapat } \\
\text { mengabdikan diri sebagai } \\
\text { guru tetap yang } \\
\text { profesional di sekolah }\end{array}$ \\
\hline
\end{tabular}

(Sumber: Analisis)

Gambar 6. Mekanisme Rekruitmen Guru yang Direkomendasikan

\section{Simpulan}

Berdasarkan hasil penelitian dan pembahasan di atas, dapat disimpulkan bahwa masalah dasar yag menjadi kendala dalam peningkatan hasil Uji kompetensi guru adalah terlelat pada faktor kapabilitas guru itu sendiri secara internal. Program apapun yang direncanakan untuk peningkatan kompetensi guru tidak akan berjalan maksimal jika tidak didukung oleh kemauan guru dalam mengembangkan kompetesni dirinya. Oleh karena itu pemerintah dan pemangku kepentingan lainnya terma- suk didalamnya pemerhati pendidikan dibutuhkan upaya serius dlaam hal peningkatan capability guru secara internal selain dari merencanakan program pelatihan, peningkatan Teknologi Informasi, perencanaan kurikulum, menambah kelengkapan sarana prasarana dans ebagainya. Karena jika masaah dasar kapabilitas internal guru ini tidak tersentuh maka selutuh program yang dijalankan tidak akan memberikan hasil yang berarti. Penulis merekomendasikan satu langkah terkait dengan rekruitmen guru, dimana rekruitken ini dalah cara berpikir sistem masuk dalam tahapan penyeim- 
bangan. Dimana proses rekruitmen guru sangat urgent untuk diperbaiki sistemnya. Penulis menyarankan untuk proses rekruitmen guru dimulai pada saat seseorang memilih perguruan tinggi yang dapat meluluskan mahasiswa menjadi seorang guru profesional. Mutu LPTK dibenahi, mahaiswa yang diterima merupakan mahasiwa yang mempunya talent guru selanjutnya dilaksanakan proses magang dan LPTK membuat kontrak kerjasama dengan sekolah dalam menyiapkan tenaga guru yang professional. Selain itu yang menjadi penghambat dari penigkatan mutu pendidikan yaitu, tidak adanya Independensi Pendidikan, dimana pendidikan sering dijadikan senjata poltik karena faktor kepentingan dan kekuasaan sekelompok elit politik. Karena faktor politisasi pendidikan yang terjadi sehingga memberikan kelemahan terhadap pengambilan keputusan dalam kebijakan pendidikan termasuk didalamnya masalah rekruitmen, baik guru maupun kepala sekolah.

\section{Daftar Pustaka}

Anonim. (2018). Ini kata Laisani soal guru honorer tidak lulus UKG. Aceh Carong. Retrieved from https://acehcarong.com/2018/02/12 /

Azhari. (2014). Upaya kepala madrasah dalam membina kompetensi Profesional Guru pada MAN Peusangan. Banda Aceh: Universitas Syiah Kuala. Retrieved from

http:/ /etd.unsyiah.ac.id/index.php?p =show_detail\&id=7281

Boyatzis, R. E. (1982). The compotent manager: amodel for effective performance. London: Wiley.

Boyatzis, R. E. (2008). Competencies in the 21st century. Journal of Management Development, 27(1), 5-12. https:// doi.org/10.1108/02621710810 840730

Bray, D. W., Campbell, R. J., \& GRant, D. L. (1974). Formative years in business: a long term ATET study of managerial lives. New York: John Wiley \& Sons,
Inc.

Efendi, J. (2017). Supervisi akademik kepala sekolah dalam meningkatkan profesional guru di SMA Negeri I Blang Pidie.

Banda Aceh: Universitas Syiah Kuala.

Retrieved from

http://etd.unsyiah.ac.id/index.php?p

=show_detail\&id=31146

Hoffmann, T. (1999). The meanings of competency. Journal of European Industrial Training, 23(6), 275-286. https:/ / doi.org/10.1108/03090599910 284650

Howard, A., \& Bray, D. (1988). Managerial lives in transition: advancing age and changing times. New York: Guilford Press.

Kementerian Pendidikan dan Kebudayaan. (2017). Neraca pendidikan daerah. Retrieved November 12, 2017, from https://npd.kemdikbud.go.id/?appid $=\mathrm{ukg}$

Kotter, J. P. (1982). The general managers. New York: Free Press.

Luthans, F., Campbell, R. J., \& Grant, D. L. (1974). Real managers. Cambridge, MA: Ballinger Press.

Menteri Pendidikan Nasional. Peraturan Menteri Pendidikan Nasional Republik Indonesia Nomor 16 Tahun 2007 tentang Standar Kualifikasi Akademik dan Kompetensi Guru (2007).

Miles, M. B., \& Huberman, A. M. (1994). Qualitative data analysis: an expanded source book. Thousand Oaks: Sage Publications, Inc.

Nasruddin. (2014). Manajemen peningkatan kompetensi profesional guru untuk meningkatkan mutu pendidikan di SMP Negeri 2 Jangka Kabupaten Bireun. Banda Aceh: Universitas Syiah Kuala. Retrieved from http://etd.unsyiah.ac.id/index.php?p =show detail\&id $=7784$

Novauli, F. (2015). Kompetensi guru dalam 
peningkatan prestasi belajar pada SMP Negeri dalam Kota Banda Aceh. Jurnal Administrasi Pendidikan:

Program Pascasarjana Unsyiah, 3(1).

Retrieved from

http://www.jurnal.unsyiah.ac.id/JAP /article/view/2524

Nurhayati. (2010). Manajemen mutu pendidikan. Bandung: Alfabet.

Presiden Republik Indonesia. UndangUndang No. 14 Tahun 2005 tentang Guru dan Dosen (2005). Jakarta.

Rahmatillah, Ruslan, \& Hasan, H. (2017). Persepsi guru sekolah dasar terhadap pelaksanaan uji kompetensi guru (UKG) di Kabupaten Aceh Utara (suatu penelitian di Kecamatan Lhoksukon). Jurnal Ilmiah Mahasiswa Pendidikan Guru Sekolah Dasar, 2(2). Retrieved from http://www.jim.unsyiah.ac.id/pgsd/ article/view/4849

Ristiyani, R., \& Wijayanti, W. (2014).

Peningkatan kompetensi guru sekolah dasar Budi Mulia Dua Seturan, Depok, Sleman. Jurnal Akuntabilitas Manajemen Pendidikan, 2(2), 217-232. https:// doi.org/10.21831/amp.v2i2.2 450

Rosita, R. (2015). Strategi kepalasekolah dalam meningkatkan kompetensi profesional guru pada SD Negeri Unggul Montasik. Banda Aceh: Universitas Syiah Kuala. Retrieved from http://etd.unsyiah.ac.id/index.php?p =show detail\&id $=13858$
Senge, P. M. (1990). The fifth discipline: the art and practice of the learning organization. New York: Currency Doubleday, a division of Bantam Doubleday Dell Publishing Group, Inc.

Setiawan, S. (2018). Pengembangan kompetensi profesional guru oleh kepala madrasah melalui penelitian tindakan kelas pada MIN Garot Kabupaten Pidie. Banda Aceh: Universitas Syiah Kuala. Retrieved from http:/ / etd.unsyiah.ac.id/index.php?p =show detail\&id=40265\#

Susanti, A. (2015, November 4). Kesiapan guru hadapi UKG. OKENEWS. Retrieved from https://news.okezone.com/read/201 5/11/04/65/1243523/kesiapan-guruhadapi-ukg

Syakir, M. J., \& Pardjono, P. (2015). Pengaruh kepemimpinan kepala sekolah, motivasi kerja, dan budaya organisasi terhadap kompetensi guru SMA. Jurnal Akuntabilitas Manajemen Pendidikan, 3(2), 226-240. https:// doi.org/10.21831/amp.v3i2.6 339

Woodruffe, C. (1992). What is meant by a competency. In R. Boam \& P. Sparrow (Eds.), Desihning and Achieving Competency. Maindenhead: McGrawHill. 